\title{
Observations on Squamous Cell Carcinoma in the Horse
}

\section{Summary}

The authors study the neoplastic disease in horses, with particular reference to squamous cell carcinoma. Of 1211 examined horses 42 were affected by neoplastic disease - $14(33,33 \%)$ tumors were of the S.C.C type. A number of facts were collected and listed regarding age, sex, breed and localisation. Some possible predispositions are mentioned. The finding of the diagnosis by different means, the treatment and therapy and a way of making a prognosis by classification based on the degree of cell differentiation are discussed.

The authors emphasize that an early diagnosis makes less invasive surgery necessary and gives an extreme favourable prognosis. They all agree that a diagnosis of S.C.C. cannot be made without a thorough histological examination.

key words: Squamous cell carcinoma, diagnosis, therapy, prognosis

Plattenepithelkarzinome beim Pferd

Die Autoren untersuchten Hauttumoren deren Anteil an allen Neubildungen $45 \%$ beträgt. An erster Stelle der beim Pferd auftretenden Neoplasien steht das Equine Sarcoid, gefolgt vom Plattenepithelkarzinom.

Definiert wird das Plattenepitelkarzinom als maligner Hauttumor, der meist die mucocutanen Übergänge, wie beispielsweise das Auge, das externe Genitale, die Nüstern, den weichen Gaumen und die paranasalen Sinus befällt. Anhand der Entwicklung werden beim Plattenepithelkarzinom zwei Typen unterschieden. Typ I zeigt blumenkohlartige Wucherungen, welche zu Blutungen neigen, und Läsionen verschiedener Größe aufweisen, die mit Ulzerationen einhergehen. Proliferatives Wachstum ist kennzeichnend. Beim Typ II werden oberflächliche Ulzera mit reichlich Sekretion beobachtet, die verstärkt infiltratives Wachstum zeigen. Beide Typen sind Beispiele für die Entartung des Stratum Spinosum der Epidermis.

Der Grad der Malignität ist verschieden, die gewebevernichtende Wirkung und das Wachstum sind erheblich. Die Entwicklung von Metastasen wird jedoch erst zu einem späteren Zeitpunkt beobachtet.

Wie in den meisten Fällen von tumorösen Zubildungen ist auch im Falle des Plattenepithelkarzinoms die Ätiologie weitgehend ungeklärt. Manche Beobachtungen lassen aber Rückschlüsse $z u, d a ß$ es eine ganze Reihe prädisponierender Faktoren gibt, wie beispielsweise das Alter, ein schwach- oder unpigmentiertes Fell oder auch Erkrankungen, die Photosensibilität begünstigen.

Im Rahmen der Studie wurden 1211 Pferde untersucht. $42(3,47 \%)$ waren von Hauttumoren betroffen. Unter den verschiedenen Typen der Zubildungen fanden sich 14 Plattenepithelkarzinome $(33,33 \%)$. Alle vorgefundenen Veränderungen waren ernsthaft und betrafen das externe Genitale [ 10 Fälle: Vulva und Perineum 1; Penis und Präputium 9], die Nüstern [ 1 Fall ], das Augenlid, die Konjunktiva und die Backe [ 1 Fall].

Die Diagnose wurde mittels klinischer Untersuchung und histologisch gestellt.

In zwei Fällen traten bis 90 Tage post operationem Rezidive auf, die wieder entfernt wurden - weitere Probleme sind hier nicht aufgetreten. Zwei Pferde mit Plattenepithelkarzinom am Penis mußten, nachdem es gerade 30 Tage nach Entfernung am Präputium und am Penisstumpf zu schnellwüchsigen Sekundärzubildungen kam, eingeschläfert werden. Die Inguinallymphknoten waren bei beiden Pferden zum Zeitpunkt des Eingriffes bereits betroffen, so daß eine lymphohaematogene Ausbreitung it rapidly destroys the limitrophic tissue first spreading to the regional lymph nodes and then to the lungs. Cases of 
metastasis of the thoracic rachis (Morgan 1969, Patterson 1990) are also reported of the udder, the muscles (gracilis), invasion of the eye socket and destruction of the eye ball with metastasis of the surface parotidean lymph nodes, metastases of the heart, lungs, liver and kidneys $(J u b b$ and Kennedy 1970).

Of extreme importance are the areas which the S.C.C. generally tend to attack, the serious damage from the aesthetical point of view together with the functional disorders that occurs to the sick animal as a result of an inevitable surgical excision.

As is the case with most neoplastic growths, the aetiology of squamous cell carcinoma is still unknown. Certain existing situations however lead us to surmise that at least some of the animals affected, may in fact have a predisposition to this type of disease. Generally speaking, the horses affected are over eight years of age with a depigmented or poor coat which gives insufficient protection against light rays, especially ultra-violet rays (Carta 1940). Also affected are horses suffering from diseases which increase photosensitization. S.C.C. could therefore originate from pre-existing papillomatous forms or carcinogenic agents in the smegma (Cotchin 1977). According to Freeman (1964) and Owen (1978) draughts and damp atmosphere probably accelerate carcinogeneses which may have been generated by ultra-violet rays.

\section{Materials and Methods}

From August 1989 till the end of November 1993 (approx. four years) 1211 horses were subjected to repeated diagnostic check ups at the Veterinary Surgery Clinic at the Faculty of Parma University. Of these horses 42 (3.47\%) were found to be affected by neoplastic disease (Tab. I). Out of the various types of neoplasm encountered, 14 were of the S.C.C. type (Table II), an incidence, therefore, of $33.33 \%$. These neoplastic growths were situated in various anatomical areas, in varying degree of diffusion.

The 14 horses with S.C.C were aged between 7 and 21 years and of different breed and sex (Table II). Six of them, from South America, had dappled coats and depigmented areas of skin. The lesions found, all extremely serious, attacked the external genitalia [10 cases: vulva and perineum 1 case, penis and prepuce 9 cases (Figs. 1 and 2)], nostrils [1 case (Fig. 3)], eyelids and conjunctiva, cheek [1 case ].

The diagnosis was based on a clinical examination, sometimes after administration of sedatives, and histological tests on biopsy samples or on surgically removed anatomical parts.

In all 14 cases, treatment consisted of extensive excision of the affected area by means of acusectors, followed by cryotherapy. Amputation was carried out in cases where the neoplastic growth had spread to cover more than $50 \%$ of the organ and regional lymph nodes were removed in cases of tumour of the penis and/or prepuce, according to the technical instructions of Mcllwraith and Turner (1987). schon abgelaufen war. Das Pferd, dessen Auge betroffen war, erlitt keinen Rückfall, was wahrscheinlich auf die "großzügige" Entfernung des 3. Augenlids zurückzuführen ist. Bei der Stute deren Vulva schwer in Mitleidenschaft gezogen war, wurde die Problematik einer Pneumovagina durch plastische Chirurgie gelöst.

Die Autoren sind der Meinung, daß die Diagnose „Plattenepithelkarzinom" nicht ohne gründliche histologische Untersuchung gestellt werden kann, da einige andere Hauttumoren ähnliche Gestalt annehmen.

Um eine Prognose stellen zu können, ist es wichtig das Stadium der Entwicklung festzulegen. Es wird deutlich, wie wichtig die frühzeitige Diagnose ist, um das Übergreifen der Neoplasie auf gesundes Gewebe möglichst einzudämmen. Zudem bedeutet die rechtzeitige Erkennung, daß der folgende chirurgische Eingriff nicht so extrem und weitläufig durchgeführt werden muß wie zu einem späteren Zeitpunkt.

Was die Therapie anbelangt, muß gesagt werden, daß in der Literatur auch andere Behandlungen, wie die Immuntherapie mit B.C.G., antimitotische Präparate und Bestrahlungsversuche, Erwähnung finden.

Die Autoren sind in Übereinstimmung mit anderen Autoren davon überzeugt, daß eine großzügige, großflächige Exzision des Tumors begleitet von Kryotherapie immer noch die Behandlung der Wahl darstellt.

Schlüsselwörter: Plattenepithelkarzinom, Diagnose, Therapie, Prognose

Surgical excision was always extensive, well beyond the neoplastic area and into the healthy tissue so as to avoid leaving tumourous elements in situ.

The operations were carried out under general gas anaesthesia according to a standard protocol: 16 hour fast; preanaesthetic medication with acepromazine maleate (Prequillan ${ }^{\circledR}$, Fatro, Bologna) in doses of $0.03-0.05 \mathrm{mg} / \mathrm{Kg}$ administered intravenously; induction with guaiacolglyceric ether (E.G.G. $8 \%{ }^{\circledR}$, Arcafarm, Bologna) in doses at $8 \%$ $80-120 \mathrm{mg} / \mathrm{Kg}$ by fast intravenous injection; pentothal sodium (Penthotal Sodium ${ }^{\circledR}$, Abbot, Latina) at $10 \%$ $2-4 \mathrm{mg} / \mathrm{Kg}$ intravenously. General anaesthesia consisting of a mixture of $50 \%$ oxygen and nitrous oxide $(8.0-12$ $\mathrm{ml} / \mathrm{Kg} / \mathrm{min}$.) and halothane (Halothane ${ }^{\circledR}$, Hoechst, Milano) was used for maintenance.

The postoperative period consisted of a wide-spectrum course of antibiotics plus local medication twice daily with antiseptics and cicatrizant ointments for the 15 days following surgery.

\section{Results}

The results obtained (Tab.II), although not far removed from those already described by other authors, deserve some consideration: the first important point to note is that in all cases the removal of the S.C.C. resulted in serious mutilations, sometimes causing functional alterations of the area or areas of the organs affected. 
Table I: Horses affected by neoplastic disease August 1989 - November 1993

\begin{tabular}{|c|c|c|c|c|c|}
\hline Type of neoplasia & Breed & Sex & Coat & $\begin{array}{l}\text { Age in } \\
\text { years }\end{array}$ & Area affected \\
\hline $\begin{array}{l}\text { Granulomatosis due to } \\
\text { vegetal foreign bodies }\end{array}$ & $\begin{array}{l}\text { Italian saddler } \\
\text { Irish saddler }\end{array}$ & $\begin{array}{l}M G \\
M G\end{array}$ & $\begin{array}{l}\text { Bay } \\
\text { Sorrel }\end{array}$ & $\begin{array}{l}13 \\
12\end{array}$ & $\begin{array}{l}\text { Left cheek } \\
\text { Lower lip }\end{array}$ \\
\hline Fibromyxoma & Arab & $\mathrm{F}$ & Grey & 9 & Abdomen \\
\hline Osteosarcoma & Thoroughbred & M & Sorrel & 9 & Left maxillary \\
\hline Myxosarcoma & Thoroughbred & $M$ & Bay & 7 & Right cheek \\
\hline Sarcoid & $\begin{array}{l}\text { Avelign. breed } \\
\text { Argentinian s. }\end{array}$ & $\begin{array}{l}F \\
M G\end{array}$ & $\begin{array}{l}\text { Sorrel } \\
\text { Sorrel }\end{array}$ & $\begin{array}{l}10 \\
13\end{array}$ & $\begin{array}{l}\text { Left hock } \\
\text { Neck }\end{array}$ \\
\hline Fibroma & $\begin{array}{l}\text { Italian s. } \\
\text { Trotter } \\
\text { Dutch s. }\end{array}$ & $\begin{array}{l}F \\
M \\
M G\end{array}$ & $\begin{array}{l}\text { Sorrel } \\
\text { Bay } \\
\text { Bay }\end{array}$ & $\begin{array}{c}7 \\
1 \\
16\end{array}$ & $\begin{array}{l}\text { Neck } \\
\text { Left hock } \\
\text { Abdomen }\end{array}$ \\
\hline Papilloma & $\begin{array}{l}\text { Maremmano breed } \\
\text { Argentinian s. } \\
\text { Italian s. } \\
\text { Italian s. } \\
\text { Argentinian s. } \\
\text { Dutch s. } \\
\text { Italian s. } \\
\text { Dutch s. }\end{array}$ & $\begin{array}{l}F \\
M G \\
M G \\
M G \\
M G \\
M G \\
M \\
F\end{array}$ & $\begin{array}{l}\text { Grey } \\
\text { Sorrel } \\
\text { Sorrel } \\
\text { Sorrel } \\
\text { Bay } \\
\text { Grey } \\
\text { Bay } \\
\text { Bay }\end{array}$ & $\begin{array}{c}7 \\
7 \\
3 \\
12 \\
13 \\
10 \\
2 \\
10\end{array}$ & $\begin{array}{l}\text { Sternum } \\
\text { Right ear } \\
\text { Abdomen } \\
\text { Neck } \\
\text { Right eye, Neck } \\
\text { Left Nostril } \\
\text { Lower lip } \\
\text { Neck }\end{array}$ \\
\hline Granulomatous cell tumour & $\begin{array}{l}\text { Thoroughbred } \\
\text { German s. }\end{array}$ & $\begin{array}{l}\mathrm{F} \\
\mathrm{F}\end{array}$ & $\begin{array}{l}\text { Bay } \\
\text { Bay }\end{array}$ & $\begin{array}{c}11 \\
8\end{array}$ & $\begin{array}{l}\text { Right ovary } \\
\text { Right Ovary }\end{array}$ \\
\hline Hemangiosarcoma & Trotter & $\mathrm{F}$ & Bay & 13 & Left cheek \\
\hline Melanoma & $\begin{array}{l}\text { Irish saddler } \\
\text { Italian s. } \\
\text { Arab } \\
\text { Arab } \\
\text { Polish s. } \\
\text { Arab } \\
\text { Quarter Horse }\end{array}$ & $\begin{array}{l}M G \\
F \\
M \\
M \\
M G \\
F \\
M\end{array}$ & $\begin{array}{l}\text { Grey } \\
\text { Grey } \\
\text { Grey } \\
\text { Bay } \\
\text { Grey } \\
\text { Grey } \\
\text { Isabel. }\end{array}$ & $\begin{array}{c}13 \\
12 \\
6 \\
20 \text { months } \\
15 \\
14 \\
10\end{array}$ & $\begin{array}{l}\text { Anus and prepuce } \\
\text { Tail and anus } \\
\text { Right jaw } \\
\text { Front left Metacorpus } \\
\text { Tail and anus } \\
\text { Tail and anus } \\
\text { Anus and right parotid gland }\end{array}$ \\
\hline $\begin{array}{l}\text { Squamous cell carcinoma } \\
\text { (S.C.C.) }\end{array}$ & $\begin{array}{l}\text { Argentinian s. } \\
\text { Dutch s. } \\
\text { Irish s. } \\
\text { Belgian s. } \\
\text { Paint Horse } \\
\text { Argentinian s. } \\
\text { Argentinian s. } \\
\text { Welsh Pony } \\
\text { Argentinian s. } \\
\text { Trotter } \\
\text { Quarter horse } \\
\text { Irish s. } \\
\text { Quarter horse } \\
\text { Argentinian s. }\end{array}$ & $\begin{array}{l}M G \\
M G \\
M G \\
M G \\
F \\
M G \\
M G \\
F \\
M G \\
M G \\
F \\
M \\
M G \\
M G\end{array}$ & $\begin{array}{l}\text { Dappled } \\
\text { Bay } \\
\text { Sorrel } \\
\text { Bay } \\
\text { Dappled } \\
\text { Dappled } \\
\text { Dappled } \\
\text { Bay } \\
\text { Dappled } \\
\text { Bay } \\
\text { Grey } \\
\text { Dark bay } \\
\text { Bay } \\
\text { Dappled }\end{array}$ & $\begin{array}{c}13 \\
15 \\
21 \\
10 \\
7 \\
8 \\
16 \\
17 \\
16 \\
12 \\
15 \\
10 \\
13 \\
15\end{array}$ & $\begin{array}{l}\text { Penis and prepuce } \\
\text { Penis and prepuce } \\
\text { Glans } \\
\text { Penis and prepuce } \\
\text { Vulva } \\
\text { Left nostril } \\
\text { Penis and lymph nodes } \\
\text { Lower left eyelid } \\
\text { Penis and lymph nodes } \\
\text { Penis and prepuce } \\
\text { Right conjunctiva } \\
\text { Lower lip } \\
\text { Glans } \\
\text { Penis }\end{array}$ \\
\hline
\end{tabular}


Table II: Horses treated for S.C.C August 1989 - November 1993

\begin{tabular}{|c|c|c|c|}
\hline Breed & Area affected & Treatment & Result \\
\hline Argentinian saddler & Penis and prepuce & $\begin{array}{l}\text { Amputation of penis and internal } \\
\text { plastic membrane of prepuce }\end{array}$ & Positive \\
\hline Dutch s. & Penis and prepuce & $\begin{array}{l}\text { Amputation of penis and internal } \\
\text { plastic membrane of prepuce }\end{array}$ & $\begin{array}{l}\text { Relapse after } 90 \text { days } \\
\text { Further surgery positive }\end{array}$ \\
\hline Irish saddler & Glans & Amputation & Positive \\
\hline Belgian saddler & Penis and prepuce & $\begin{array}{l}\text { Amputation of penis and internal } \\
\text { plastic membrane of prepuce }\end{array}$ & $\begin{array}{l}\text { Relapse after } 110 \text { days } \\
\text { Further surgery positive }\end{array}$ \\
\hline Paint Horse & Vulva & Left vulvectomy & Positive after plastic surgery \\
\hline Argentinian saddler & Left nostril & Removal of mucosa and cryotherapy & Positive \\
\hline Argentinian saddler & Penis and lymph nodes & $\begin{array}{l}\text { Amputation and removal of } \\
\text { inguinal lymph nodes }\end{array}$ & $\begin{array}{l}\text { Relapse after } 30 \text { days } \\
\text { Euthanasia }\end{array}$ \\
\hline Welsh Pony & Lower left eyelid & Partial removal & Positive \\
\hline Argentinian saddler & Penis and lymph nodes & $\begin{array}{l}\text { Amputation and removal of } \\
\text { inguinal lymph nodes }\end{array}$ & $\begin{array}{l}\text { Relapse after } 40 \text { days } \\
\text { Euthanasia }\end{array}$ \\
\hline Trotter & Penis and prepuce & $\begin{array}{l}\text { Amputation of penis and internal } \\
\text { plastic membrane of prepuce }\end{array}$ & Positive \\
\hline Quarter Horse & Right conjunctiva & Removal of nictitating & Positive \\
\hline Irish saddler & Lip and left cheek & Partial removal & Positive \\
\hline Quarter Horse & Glans & Amputation & Positive \\
\hline Argentinian saddler & Penis & Amputation & Positive \\
\hline
\end{tabular}

In 2 cases, 90 days after surgery a new neoplastic growth appeared in the area surrounding the primary lesion. The horses then underwent a further surgical treatment, with extensive peripheral exeresis. This second operation appears, to date, to have resolved the problem definitively. Two horses with S.C.C. of the penis had to be put down as the neoplasia re-appeared very soon only 30 days after the operation. The relapse involved the internal membrane of the prepuce and the penile stump. In both cases, moreover, there were also micturation problems either due to cicatricial stenosis of the urethra or to compression of the urethra by the rapidly forming neoplastic masses.

Here it is important to mention that at the time of surgery, the inguinal lymph nodes of both horses were already affected, and it is therefore clear that the neoplasm was already spreading by lymphohematogenous route. The autopsy did not reveal metastases of other organs or tissues.

The horse with S.C.C. of the conjunctiva did not suffer from any kind of relapse; we believe that this may be attri- buted to the extensive exeresis of the conjunctival mucosa and to the total removal of the third eyelid.

The horse affected by S.C.C. of the left vulvar lip was so badly mutilated after the operation (unilateral vulvectomy) that plastic surgery was required in order to resolve the pneumovaginal state which occurred during the recovery period following the first operation.

\section{Considerations and conclusions}

The conclusions which may be drawn from an analysis of our study population are as follows:

A diagnosis of S.C.C. cannot be made without the help of a thorough histological examination, since several different skin tumours in the horse have a similar appearance; often in fact the term ,sarcoid“ tends to be used to classify a series of skin growths which, on closer analysis, turn out to 


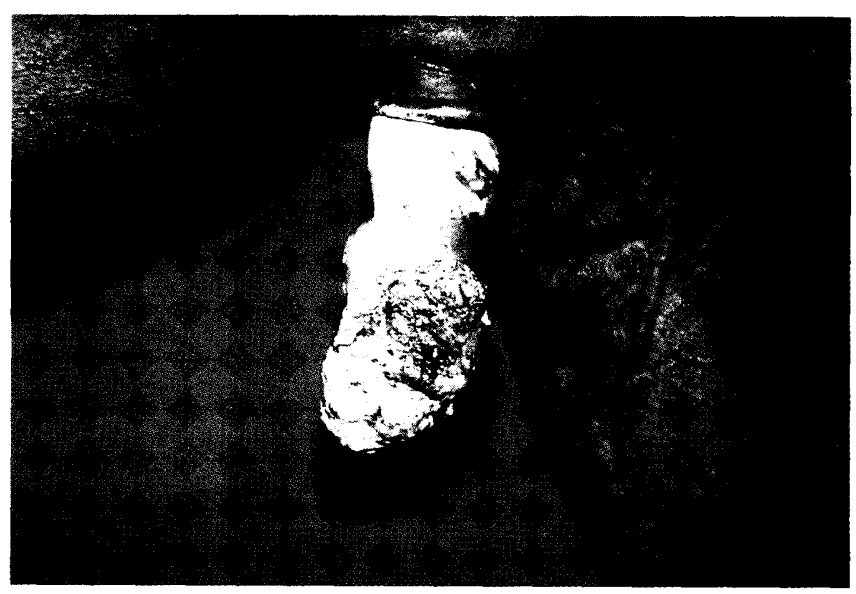

Fig. 1: Argentinian saddler, male gelding, dappled, 16 years old. Extensive and severe damage to the proximal part of the penis.

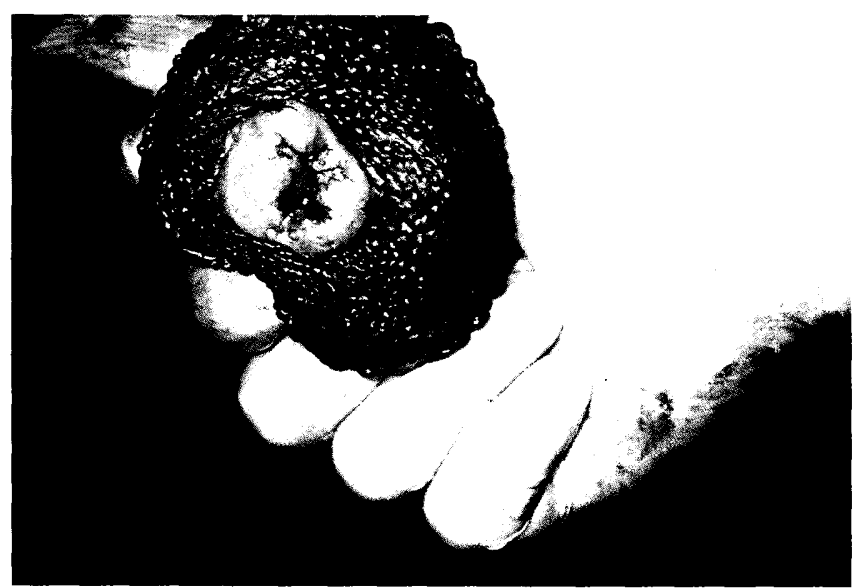

Fig. 2: Quarter Horse, male gelding, bay, 13 years old. Carcinoma affecting the urethral opening with visible ulceration of the mucosa.

be of a completely different nature, including granulomas due to vegetal foreign bodies.

A favourable prognosis is linked to being able to define the stage of evolution of a S.C.C.. To this end, a classification staging was developed by Broders in 1932, based on the degree of cell differentiation, which divided the S.C.C. into 4 distinct stages of evolution.

- Stage I: at least $75 \%$ of the tumorous cells remain differentiated;

- Stage II: between $50 \%-75 \%$ of the cells are differentiated;

- Stage III: between $25 \%-50 \%$ of the cells are differentiated;

- Stage IV: less than $25 \%$ of the cells are differentiated.

In the light of this classification, it is obvious just how important a correct and early diagnosis actually is, so as to prevent the healthy tissue surrounding the neoplasia from being invaded by the carcinogenic cells.

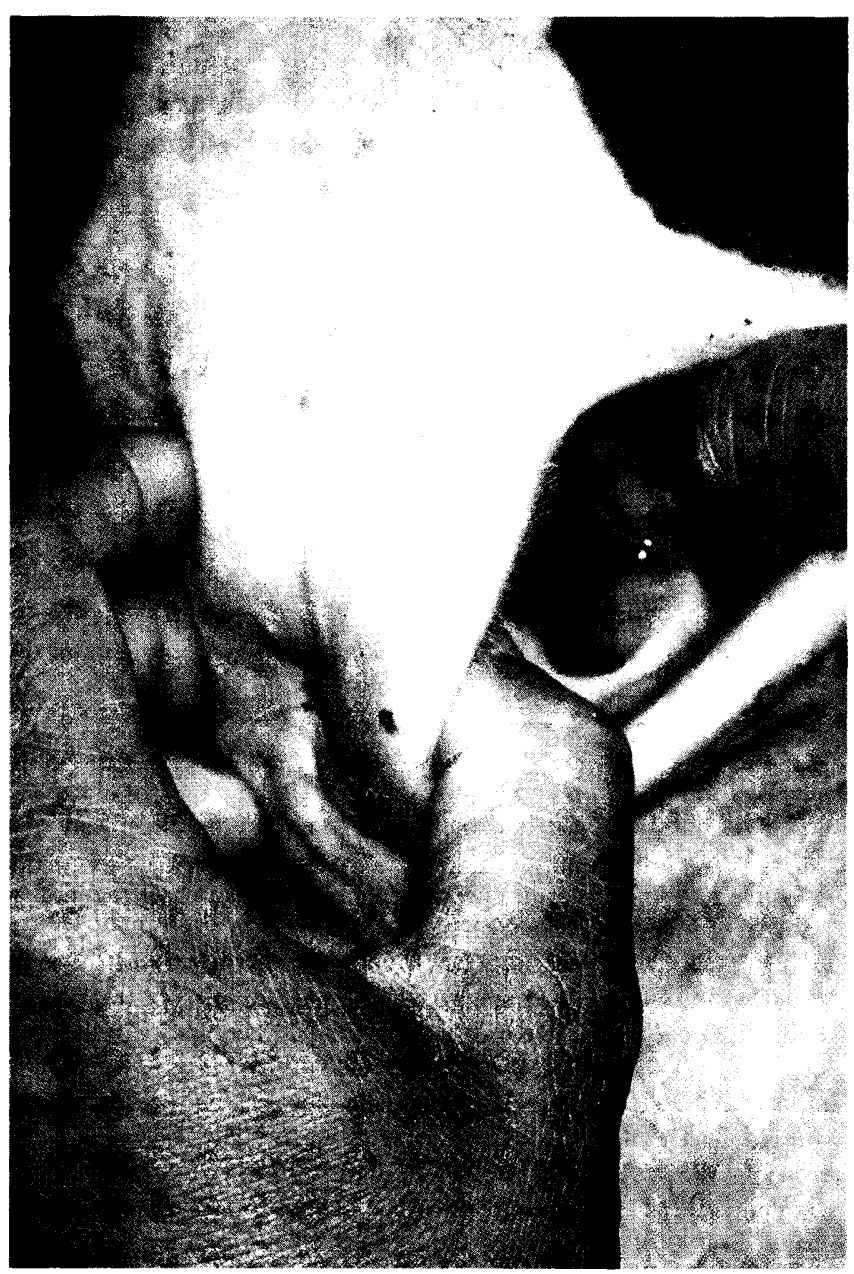

Fig. 3: Argentinian saddler, male, dappled, 8 years old. Carcinomatous, ulcerated and bleeding proliferation affecting the mucocutaneous junction of the nostril.

An early diagnosis means that less invasive and more specific surgery may be performed with an extremely favourable prognosis. It is important to remember that in cases of Stage III and IV S.C.C., where the lymph nodes and/or other limitrophic anatomical sectors are already affected, the prognosis can only be unfavourable and reserved.

Regarding treatment, various pharmacological or other, attempts have also been reported in literature (immunotherapy with B.C.G., antimitotic agents, radiation therapy etc.). We are thoroughly convinced, in accordance with most authors, that extensive surgical exeresis backed up by cryotherapy is still the main therapeutical means to which we should dedicate our attention. In second place where necessary, drugs may also be used in order to stimulate an aspecific immune response, although the fact remains that the earlier the diagnosis, the better the therapeutical results obtained: it is well-known that in the initial phases (Stage I S.C.C.) the chronic inflammatory reaction is more severe than it is in the more advanced carcinomatous phases and that, when the invasion of tumorous cells begins, the host is able to react very efficiently (Lever 1975).

An accurate diagnosis is of ultimate importance, as confusion with similar types of disease (habronemiasis of the 
skin, granulomatous lesions, squamous papilloma, secondary adenolymphitis, ulcers of various origins etc.) could lead to time being wasted prior to surgery, thus jeopardising its outcome.

\section{Acknowledgements}

The authors wish to thank Prof. Enrico Cabassi, Director of the Institute of Veterinary Pathological Anaromy, University of Parma, and his Assistant, Prof. Attiloi Corradi, for their valuable assistance in checking the histopathological diagnoses of the cases reported.

\section{References}

Baker J.R. and A. Leyland (1975): Histological survey of tumours of the horse, with particular reference to those of the skin. Vet. Rec., 96, 419.

Bourdeau P. (1992): Carcinoma spino-cellulare del gatto. Sumrna, 3, 35.

Boure L., J.M. Krawiecki and F. Thoulon (1991): Essai de traitement des sarcoides du cheval par injections intra-tumorales de bleomycine. Le Point Vet., 23, 199.

Broders (1932): Practical point on the microscopic grading of carcinoma. Journal of Medicine, New York State, 32, 667.

Buracco P., R.C. Richardson, C. Capurro, C. Pellegrino and L. Rossi (1988): Oncologia comparata: studio e cura dei tumori spontanei negli animali da compagnia e definizione di modelli neoplastici utili ai fini comparativi. Veterinaria, 2, 15 .

Catcott E.J. (1980): Trattato di medicina e chirurgia del cavallo. Ed. It. annetti G., Del Bue M., Edizioni Medico Scientifiche, Torino.

Chesney J. (1980): A technique for amputation ofthe equine penis. Equine Vet. J., 12, 212

Cotchin E. (1960): Tumours of farm animals: a survey of tumours examined at the Royal Veterinary College, London, during 1950-1960. Vet. Rec., 72, 40, 816.

Cotchin E. (1977): A general survey oftumours in the horse. Equine Vet. J., 9, 16.

De Gresti A., L. Mertel and M. Finazzi (1992): Un adenocarcinoma sebaceo nel cavallo. Ippologia, 3, 67.

Dietz $O$. and W. Holdhaus (1986): Zur Penischirurgie beim Pferd. Mh. Vet.Med., 41, 349

Fraunfelder F.T., H. Farris, M. Howard and M.L. Ray (1973): New therapy method for cancer eye in cattle. Arkansas Farm Research, 1112,5 .

Freeman R.G. and J.M. Knox (1964): Influence of temperature on ultraviolet injury. Archives of dermatology, 89, 859.

Gatewood D.M., J.H. Cox and R. DeBowes (1989): Diagnosis and treatment of acquired pathologic conditions ofthe equine penis and prepuce. Comp. Cont. Ed., 11, 1498.

Gilson S.D. and E.A. Stone (1990): Priciples of oncologic surgery. Comp. Cont. Ed., 12, 827 .

Heck F.C. and R.B. England (1977): Manifestations of immunotherapy in cases of bovine ocular squamous cell carcinoma. Vet. Med./Small An. Clin., 1767.

Howarth S., V.M. Lucke and H. Pearson (1991): Squamous cell carcinoma of the equine external genitalia: a review and assessment of penile amputation and urethrostomy as a surgical treatment. Equine Vet. J., 23, 53 .

Howie F., G. Munroe, H. Thompson and D. Murphy (1992): Palatine squamous cell carcinoma involving the maxillary sinus in two horses. Equine Vet. Educ., 4, 3.

Junge R.E., J.O. Sundberg and W.D. Lancaster (1984): Papillomas and squamous cell carcinoma of horse. JAVMA, 168, 61.

Krawiecki J.M. (1992): Le neoplasie cutanee del cavallo. Summa, 7, 29.

Krawiecki J.M., L. Boure and F. Thoulon (1992): Il sarcoide del cavallo. Summa, 7, 37.
Lever W.F. (1975): Histopathology ofthe skin. Lippincot Co, Philadelphia, 477.

Marcato P. (1981): Anatomia ed istologia patologica speciale dei mammiferi domestici. Edagricole, II edizione.

McIlwraith C.W. and A.S. Turner (1987): Equine surgery advanced techniques. Lea \& Febiger, Philadelphia.

Micheletto B. (1980): Patologia chirurgica veterinaria e podologia. UTET, Torino.

Montes L.F. and J.T. Vaughan (1984): La pelle del cavallo. Edizione italiana, Edi-Ermes, Milano.

Murphy J.M., G.A. Severin, J.D. Lavach, D.I. Hepler and D.C.Lueker (1979): Immunotherapy in ocular equine sarcoid. JAVMA, 174, 3, 269.

Owen D.W. and J.M. Knox (1978): Influence of heat, wind and humidity on ultraviolet radiation injury. Comp. Int. on Ultraviolet Carcinogenesis, 161.

Patterson L.J., S.A. May and J.R. Baker (1990): Skeletal metastasis of a penile squamous cell carcinoma. Vet. Rec, 126, 579.

Pezzoli G. (1953): Epiteliomatosi multipla in un cane. La Nuova Vet., 2, 44.

Puntoni P. (1956): Di un caso di epiteliomatosi multipla del cane trattata con antimitotici. Ann. Fac. Med. Vet. Pisa, IX, 41.

Schumacher J. and J.T. Vaughan (1988): Surgery of the penis and prepuce. Vet. Clin. North Am.: Equine Pract., 4, 473.

Scott E.A. (1976): A technique for amputation ofthe equine penis. JAVMA, 168, 1047.

Strafuss A.C. (1976): Squamous cell carcinoma in horses. JAVMA, 168, 61.

Theilen G.H. and D. Hills (1982): Comparative aspects of cancer immunotherapy: immunologic methods used for treatment of spontaneous cancer in animals. JAVMA, 181, 10, 1134.

Trainin $Z$. and M. Essex (1982): Immune response to tumor cells in domestic animals. JAVMA, 181, 10, 1125.

Webster C.J. and J.M. Webster (1985): Treatment of equine sarcoids with B.C.G.. Vet. Rec., 116, 131.

Welch R.D. and R.M. DeBowes (1989): Surgical techniques for treatment of pathologic conditions of the equine penis. Comp. Cont. Ed., 11, 1505 .

Wyman M., M.D. Rings, M.J. Tarr and C.L. Alden (1977): Immunotherapy in equine sarcoid: a report oftwo cases. JAVMA, 171, 449.

Wyn-Jones $G$. (1979): Treatment of periocular tumours of horses using radioactive gold ${ }^{198}$ grains. Equine Vet. J., 11, 3 .

\section{S. Zanichelli}

G. Pezzoli

M. Del Bue

P. Scrollavezza

Institute of Clinical Veterinary Surgery

University of Parma

Via del Taglio 8

1-43100 Parma

Tel.: (0039 521) 293854

\section{P. Botri}

Department of Animal Pathology University of Turin 